\title{
Evaluating vase life and tissue structure of some compositae (Asteraceae) species
}

\author{
Tar, T. and Hassan, F. A. S. \\ SZIU Faculty of Horticultural Sciences, Department of Floriculture and Dendrology \\ 1118 Budapest, Villányi str. 35-43.
}

\begin{abstract}
Summary: The vase life of cut flowers and effects of various chemicals was examined with the help of a pulse treatment. According to the results using of chemicals (preservatives, disinfectants as well as blocking of synthesis of ethylene) is ineffective if it is used after seeding This shows the great importance of harvesting time.

Using 8-HQS or 1-MCP + 8-HQS proved to be the best for vase life in most of the samples. Using these materials did not prevent the appearance of air bubbles in the stems and absorption could be observed continuously.

To examine the tissue structure reaction of chemicals stems were stained with toluidin-blue, and high of absorption was measured. It was found that in cases, when absorption was bad, small air bubbles blocked the xylem vessels.

All the species examined (Aster linosyris, Achillea collina, Aster novi-belgii, Inula britannica, Solidago canadensis, Inula ensifolia, Senecio jacobea) show similar reactions to chemicals because they are the members of the same family.
\end{abstract}

Key words: vase life, cut flower, native plants, compositae (Asteraceae)

\section{Introduction}

Some species, members of the compositae family and applied as cut flowers (Asteraceae) were examined in this experiment. Native plants were chosen as potential ornamentals to enlarge the choice of cut flowers. The species examined were: Aster linosyris (Goldilocks), Achillea collina (Yarrow), Aster novi-belgii (Michaelmas daisy), Inula britannica (British Elecampane), Solidago canadensis (Canada Goldenrod), Inula ensifolia (Narrow-leaved Inula), Senecio jacobea (Staggerwort).

Regarding vase life of cut flowers many researches were done the length of life can be influenced by different factors. For example water deficiency after harvesting or air bubbles in the stems cause breaking off in continuity of absorption in stems (Carow, 1978). Pollution of the wound during and after harvest can also be a source of rapid wilting (Halevy \& Mayak, 1979). Ethylene and in some cases salts dissolved in water are also harmful to cut flowers. Ethylene located inside the flower causes the wilting of it, too, in addition to ethylene in air around the flower (Paulin, 1983). It is known, that added sucrose as a nutrient can supply the demand of energy that occurs after harvest. According to literature, 8-HQS (8-hydroxyquinoline sulphate) or 8-HQC (8-hydroxyquinoline citrate) can be used as fungicide and bactericide. In addition they block the closing of vessels, limit the initiation of ethylene, regulate the transport of sucrose, increase the absorbtion of water and reduce the opening of stomata (Eszéki, 1986).

Silver nitrate, silver thiosulphate or aluminium sulphate are also able to enlarge vase life of cut flowers with the help of reducing the effects of ethylene or regulating the closing and opening of stomata. Vase life can be significantly influenced with cultivation methods too (Ince, 1972).

Some retardants are also in use, such as CCC or B9, which reduce transpiration, delay maturity or block the initiation of ethylene. With the help of some growth substances sprouting can be accelerated or the time and size of the flower can be influenced (Szalai, 2001).

\section{Material and method}

\section{Examination of vase life}

Vase life of the stems was measured after having been treated with various chemicals in comparison with the control. The plants were collected partly in nature partly in a five-year-old plantation. They were transported to the laboratory of the Department of Floriculture and Dendrology, SZIU Faculty of Horticultural Sciences, Budapest, where the experiments were done.

Altogether 14 different treatments were used:

1-2.: Sugar (sucrose) was applied in $200 \mathrm{~g} / \mathrm{l}$ and $400 \mathrm{~g} / \mathrm{l}$ as a continuous treatment.

3-4.: STS (silver thiosulphate) at concentrations $200 \mathrm{ppm}$ and $400 \mathrm{ppm}$ was used as a pulse-treatment. The stems were pulsed for 6 hours, afterwards they were placed in water.

5-6.: HQS (hydroxyquinoline sulphate) was obtained as a continuous treatment like sucrose with the concentration of $200 \mathrm{ppm}$ and $400 \mathrm{ppm}$. 
7.: The fourth material was 1-MCP (1-methylcyclopropene) known as EthylBloc. This was used with the concentration of $5 \mathrm{~g} / \mathrm{m}^{3}$. Stems were placed in a box, which was closely covered with plastic. This treatment lasted for 6 hours. After the treatment stems were placed in water till the end of the experiment.

On the other hand, stems were located in boxes flooded with 1-MCP after they were placed in various solutions. In this case, they were treated in two different ways and the effects of the two materials were examined together.

The combinations of materials were:

$$
\begin{aligned}
\text { 8.: } & \text { 1-MCP + water } \\
9-10 .: & 1-\mathrm{MCP}+\text { sucrose }(200 \mathrm{~g} / \mathrm{l} \text { and } 400 \mathrm{~g} / \mathrm{l}) \\
11-12 .: & 1-\mathrm{MCP}+\mathrm{STS}(200 \mathrm{ppm} \text { and } 400 \mathrm{ppm}) \\
13-14 .: & 1-\mathrm{MCP}+\mathrm{HQS}(200 \mathrm{ppm} \text { and } 400 \mathrm{ppm}) .
\end{aligned}
$$

At the first time, all of these materials were tested with Aster linosyris. For the second time only those materials were applied which were, proved to be the bests, and these are the: HQS (200ppm and $400 \mathrm{ppm}$ ), 1-MCP, 1-MCP + water, 1$\mathrm{MCP}+\mathrm{HQS}(200 \mathrm{ppm}$ and $400 \mathrm{ppm})$ and of course the control. At the second time Aster linosyris, Inula britannica, Aster novi-belgii and Achillea millefolium were examined.

The experimental time ended at $85 \%$ mortality of the control stems.

\section{Examination of capillary energy of the stems}

Just the time when control plants wilted or died in $85 \%$ the capillary energy of stems were measured with the help of a pulse-treatment. Stems were placed into toluidin-blue for 24 hours, then the hight of the coloured part was measured. Together with this measure, tissue structure of stems was examined, with the help of an electro-microscope. The alternation of tissue structure was watched in 32, 100 and 400 multiplied enlargements.

\section{Results}

At the first time the effects of all the materials mentioned before were examined with Aster linosyris. The experiment lasted for 7 days, it was the time of the $85 \%$ mortality of the control stems. In that case mortality meant the seed formation of the stems instead of wilting. After four days $42 \%$ of the control went to seed, but there was only $5-10 \%$ of this in stems treated with HQS (200 ppm and $400 \mathrm{ppm})$, 1-MCP + water, 1-MCP + STS (200 ppm and $400 \mathrm{ppm})$ and $1-\mathrm{MCP}+\mathrm{HQS}(200 \mathrm{ppm}$ and $400 \mathrm{ppm})$. At the end of the experiment, after 7 days, the least damaged stems were the ones, which were treated with 1-MCP + HQS (200 ppm and $400 \mathrm{ppm}$ ) and 1-MCP + STS (400 ppm). The seed formation was only $8 \%$ in those cases. The treatment with $1-\mathrm{MCP}+$ water proved to be better than the treatment with 1-MCP (seed formation were 16\% against $56 \%$ ).

During the second experiment only those materials wer used, which had good results during the first one. Plant materials appearing in the second experiment were: Aster linosyris, Achillea collina, Aster novi-belgii, Inula britannica.

This experiment began ten days later than the first, so Aster linosyris was in a more advanced stage regarding seed formation than earlier. Therefore this experiment ended after 4 day as the seed formation of control stems reached $89 \%$. The best treatment was 1-MCP + HQS (400 ppm), seed formation was $37 \%$ in this case.

Achillea collina control was destroyed after ten days, one part formed seed the other wilted. The differences between various treatments were less than in the case of Aster linosyris. Samples were destroyed over $60 \%$ of all treatments: $1-\mathrm{MCP}+\mathrm{HQS}(400 \mathrm{ppm})-60 \%, 1-\mathrm{MCP}+\mathrm{HQS}$
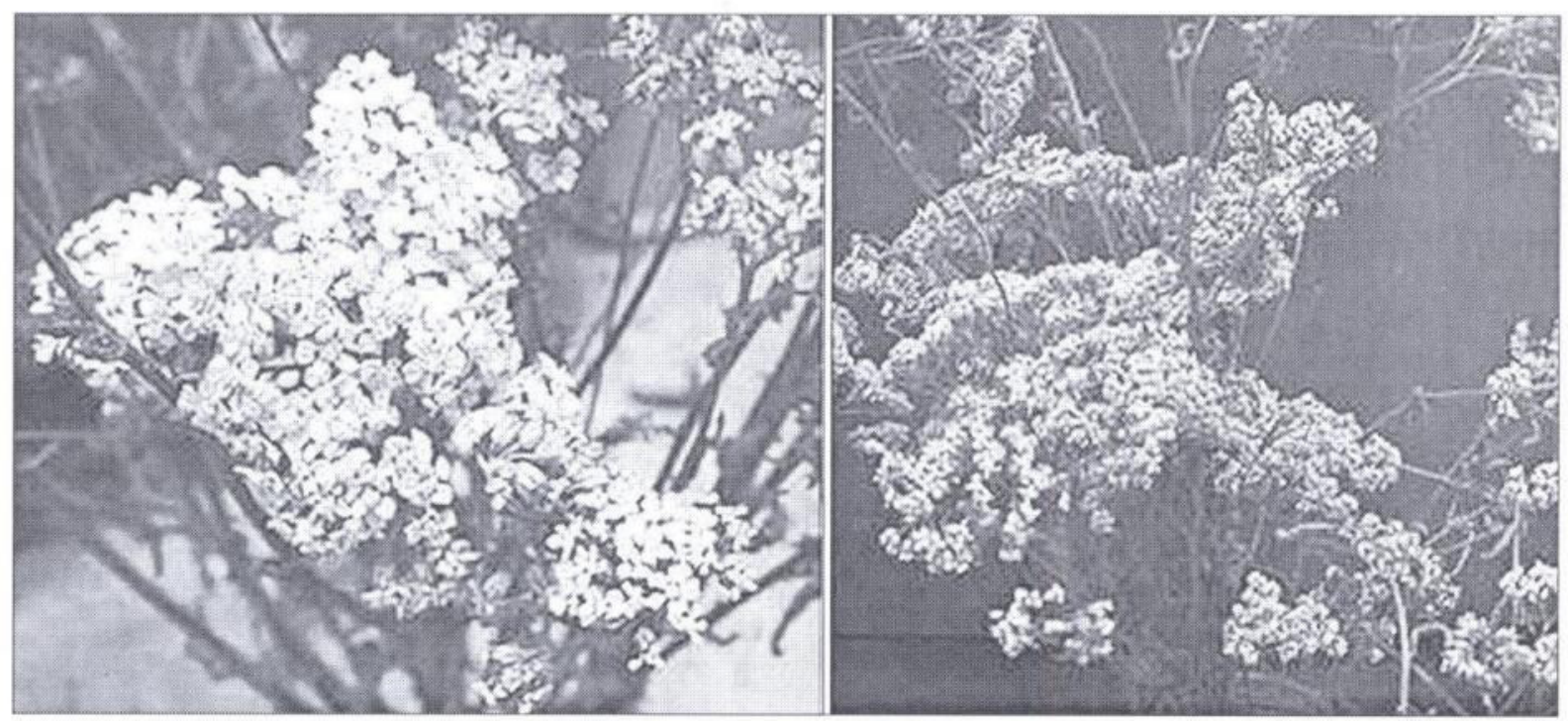

Figure I Effect of 1-MCP+HQS (400 ppm) in comparison with control in the case of Achillea collina 
(200 ppm) - 63\%, HQS (400 ppm) - 64\% (Figure I).

The blossoming of the single inflorescences and the time of seed formation were examined to Aster novi-belgii. The plantation was in full blossom at cutting, so this was the cause of fewer differences measured between various treatments. For correct measuring this treatment needs a replication with stems that will be cut at the early part of blossoming. Though it is interesting, that the mortality of control rose over $85 \%$ happened only after 11 days, which is a very long term in comparison with the 7-day-long vase life of Aster linosyris control.

The reactions of Inula britannica. differ from the others: there were no seed formation only wilting. At cutting they were in early blossom, but the plantation contained only a few stems, so there was no opportunity to make the experiment in three replicates. Therefore the result gives only little information. The control wilted in four days more than $85 \%$, but samples treated with HQS $(200 \mathrm{ppm}$ and 400 ppm), 1-MCP and 1-MCP + HQS (400 ppm) were fresh till 11 days after cutting (Figure 2).

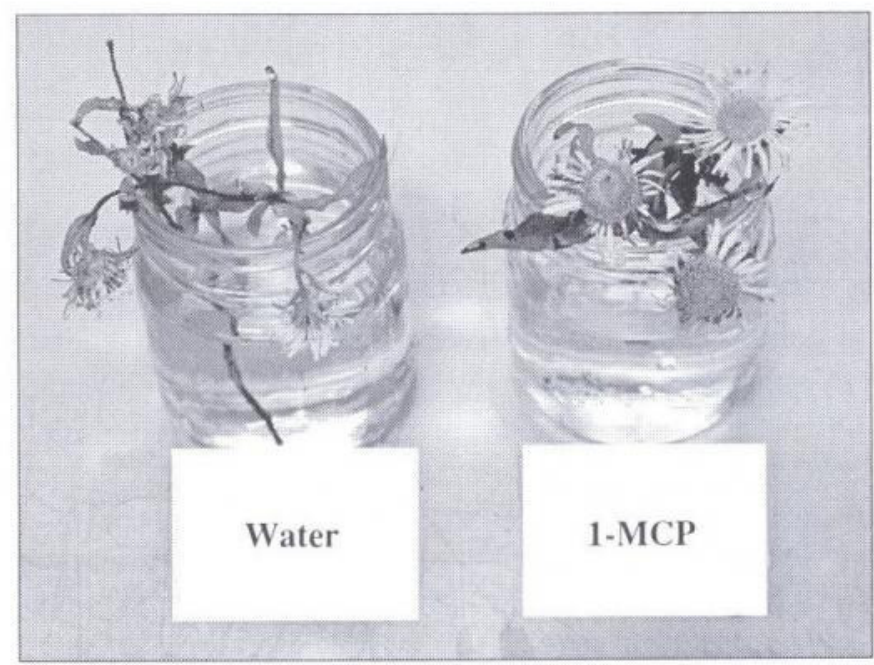

Figure 2 Inula britannica treated with 1-MCP 10 days after cutting

Just for information the vase life of three compositae (Inula britannica, Inula ensifolia, Senecio jacobea) were examined during the summer of 2002. Inula britannica proved the longest vase life, after 11 days there were still $25 \%$ freshly blossoming flowers in the stems. Inula ensifolia died at the ninth day in control circumstances, but $200 \mathrm{~g} / \mathrm{l}$ added sucrose made vase life longer with $15 \%$. The closed buds of Senecio jacobea bloomed in $53 \%$, but after nine days stems died without further blooming.

\section{Discussion}

To compare the results of a species being in floricultural use let us see the data of vase life of goldenrod (Solidago canadensis). This as fresh for 5.7 days in water, while treated with HQS (400 ppm) the vase life was 11.7 days (Hassan, Tar, 2003). Just to compare with carnation it is found, that using HQS + sucrose the vase life of carnation is 15 days, without sucrose 13.2 days (Huszár, 1990). Seeing a compositae being one of the species known from earliest time as an ornamental plant (Molnár, 1992), chrysanthemum is maintained in vase for $8-15$ days. The use of HQS $150 \mathrm{mg} / \mathrm{l}$ + sucrose $30 \mathrm{~g} / 1$ proved to be the best chemical treatment for this species (D'Hont, 1988 and Paksy, 1980). In the case of gerbera, using HQS was found the best, it prolonged the vase life with 3-4 days. Though the vase life of it depends on the variety (Sólyom, 1993 and Gleria \& Tusnádi, 1987). It was found that the native compositae species appearing in this experiment produced nearly the same in vase life as the species of compositae cultivated at the present.

Checking the tissue structure and causes of behaviour as a cut flower a colouration measure was accomplished. It was found that in most of the treated cases capillariation of stems were higher than in control circumstances. Capillariation was the highest in case of Aster linosyris $(6 \mathrm{~mm}$ - treated with HQS $400 \mathrm{ppm}$ ). The intensity of pulsing was based on the differences of species and treatments. The highest pulsing could be observed in the case of various species: Inula britannica $-5 \mathrm{~mm}$ (treated with HQS $400 \mathrm{ppm}$ ), Aster novi-belgii-4 mm (treated with 1-MCP), Achillea collina$1.5 \mathrm{~mm}$ (treated with 1-MCP + HQS $400 \mathrm{ppm}$ ).

In the cases when absorption was high, there were no bubbles found in the stems, and those samples proved to have the longest vase life.

\section{References}

Corow, B. (1978): Frischhalten von Schnittblumen. Ulmer, Stuttgart. D'Hont, K. (1988): Postharvest treatment of Chrysanthemum. Acta Hort. 261.

Erhardt, W., Götz, E. \& Bödeker, N. (2002): Zander. Handwörterbuch der Pflantzennamen. Verlag Eugen Ulmer

Eszéki, E. (1986): Vágott virág tartósítási kísérletek kardvirág, tulipán és nárcisz fajtákkal. Kertészeti és Élelmiszeripari Egyetem, Budapest.

Gleria, E. \& Tusnádi, Cs. K. (1987): A gerbera termesztése. Mezôgazdasági Kiadó, Budapest.

Halevy, A. H. \& Mayak, S. (1979): Senescence and post-harvest physiology of cut flowers. Hort. Review, Westporst 1.

Hassan, F. A. S. \& Tar, T. (2003): Extending the vase life of Solidago canadensis cut flower by using different chemical treatments. Manuscript.

Huszár, T. (1990): A növényházi szegfũ hozam- és vázatartósságának vizsgálata. Kertészeti és Élelmiszeripari Egyetem, Budapest. Incze F. (1972): A krizantém. Mezổgazdasági Kiadó, Budapest.

Molnár, J. (1992): Különféle virágtartósítószerek hatásának vizsgálata vágott virágokon. Kertészeti és Élelmiszeripari Egyetem, Budapest.

Paksy Zs. (1980): Egész évben krizantém. Mezốgazdasági Kiadó, Budapest.

Paulin, A. (1983): Improvement in the preservation of cut flowers. Acta Hort.

Sólyom, K. (1993): Hazai nemesítésú gerberafajták vázâtartóssági vizsgálata. Kertészeti és Élelmiszeripari Egyetem, Budapest.

Szalai, J. (2001): Növényi életjelenségek a kertben, Szaktudás Kiadó Ház, Budapest. 